\title{
Redesign Smart Clothesline Berbasis Arduino
}

\author{
Joni Eka Candra ${ }^{1)}$ dan Very Karnadi ${ }^{2)}$ \\ ${ }^{1,2)}$ Jurusan Teknik Informatika, Universitas Putera Batam, Indonesia \\ email: ${ }^{1)}$ jonicandra82@gmail.com, ${ }^{2)}$ veryshredder@gmail.com
}

\begin{abstract}
Abstrak- Pesat nya perkembangan teknologi seperti jaman sekarang menuntut manusia untuk selalu berinovasi dalam mengembangkan teknologi tepat guna yang dapat membantu memudahkan pekerjaan manusia dalam kegiatan sehari-hari seperti kegiatan menjemur pakaian. Menjemur pakaian merupakan salah satu kegiatan yang sering dilakukan didalam kehidupan rumah tangga, Kepulauan Batam mempunayai curah hujan yang hampir merata sepanjang tahun yaitu dengan nilai 230-280 mmtiap bulannya, dan masyarakat Kota Batam yang rata-rata bekerja di sektor industri dan pemerintahan secara tidak langsung sering berada diluar rumah sehingga kegitan menjemur pakaian biasa ditinggalkan berpergian atau bekerja, sehingga waktu turun hujan atau pada waktu hari sudah malam tidak bisa mengangkat jemuran. Maka dari permasalahan tersebut di atas maka dibuatlah jemuran otomatis (smart clothesline) menggunakan arduino dengan mendesain ulang dari jemuran otomatis yang sudah pernah diteliti yang mempunyai kelebihan lebih mudah dan praktis dalam penggunaannya dan tidak terlalu banyak membutuhkan tempat. Setelah dilakukan pengujian sistem prototype jemuran otomatis (smart clothesline), terlihat bahwa sistem prototype dapat berfungsi karena komponen-komponen yang digunakan bekerja sesuai urutannya, dan didapatkan hasil ketika sensor air dicelupkan ke dalam wadah air motor servo bergerak dari sudut $0^{\circ}$ ke sudut $90^{\circ}$ menandakan jemuran bergerak menutup dan ketika sensor air diangkat dari wadah air motor servo bergerak dari sudut $90^{\circ}$ ke sudut $0^{\circ}$ menandakan jemuran bergerak membuka. Begitu juga ketika sensor cahaya (LDR) diberi sinar cahaya maka motor servo bergerak dari sudut $90^{\circ}$ ke sudut $0^{\circ}$ menandakan jemuran bergerak membuka dan sebaliknya ketika sensor cahaya (LDR) ditutup dari terkena sinar cahaya maka motor servo bergerak dari sudut $0^{\circ}$ ke sudut $90^{\circ}$ menandakan jemuran bergerak menutup. sistem protototype telah sesuia dengan rancangan yang telah dibuat
\end{abstract}

Kata Kunci: Arduino, Sensor Cahaya (LDR), Sensor Air

\section{Pendahuluan}

Pesat nya perkembangan teknologi seperti jaman sekarang menuntut manusia untuk selalu berinovasi dalam mengembangkan teknologi tepat guna yang dapat membantu memudahkan pekerjaan manusia dalam kegiatan sehari-hari seperti kegiatan menjemur pakaian. Menjemur pakaian merupakan salah satu kegiatan yang sering dilakukan didalam kehidupan rumah tangga. Kepulauan Batam mempunayai curah hujan yang hampir merata sepanjang tahun dan masyarakat Kota Batam yang rata-rata bekerja di sektor industri dan pemerintahan secara tidak langsung sering berada diluar rumah sehingga kegitan menjemur pakaian biasa ditinggalkan berpergian atau bekerja, sehingga waktu turun hujan atau pada waktu hari sudah malam tidak bisa mengangkat jemuran, sehingga diperlukan alat jemuran yang peraktis yang dapat bekerja secara otomatis.

Dari penelitian Eko Rismawan, Sri Sulistyanti, dan Agus Trisanto, menjelaskan tentang alat penjemur pakaian otomatis yang menggunakan mikrokontroller ATMega8535 sebagai pengontrol [1], selain itu juga bisa menggunakan arduino uno Atmega328 sebagai kontrol penggerak alat jemur pakaian otomatis sebagai solusi pengangkat jemuran disaat hujan ataupun hari sudah malam [2]. Cara merancangan dan Pembuatan alat jemuran otomatis dengan sensor cahaya dan sensor deteksi basah dengan cara memanfaatkan sensor sebagai inputan untuk transistor yang kemudian dikuatkan oleh kontrol motor maka akan di hasilkan pergerakan motor sesuai sensor [3]. Sistem kendali jemuran otomatis dengan menggunakan LDR dan sensor hujan, cukup mudah untuk dirancang dan diaplikasikan. Pada saat sensor hujan mendeteksi adanya air yang berarti dalam keadaan hujan, maka basis resistor akan aktif dan mengirim input ke relay dan akan menggerakkan rel jemuran masuk, namun jika sensor hujan tidak mendeteksi adanya air maka rel jemuran akan keluar. Pada saat LDR mendapat cukup cahaya, rel jemuran akan bergerak keluar, namun pada saat senja atau malam hari maka basis transistor akan aktif dan mengirim input ke relay dan akan menggerakkan rel jemuran masuk. Penggunaan relay sebagai pengendali motor menjadikan alat ini dapat dengan mudah diaplikasikan didalam kehidupan sehari-hari [4]. Perengkat yang telah dibuat dapat bekerja dengan baik sesuai dengan yang diharapan yaitu kedua sensor dapat bekerja dengan baik, sensor LDR dapat mendeteksi adanya perbahan cahaya (dari terang ke gelap atau sebaliknya) dan sensor hujan dapat mendetksi adanya air atau tetesan air hujan, alat mampu membaca keadaan cuaca, dimana dalam kondisi panas namun ada hujan. Microcontroller Arduino uno yang digunakan sebagai pengendali utama, alat ini dapat bekerja dalam menjalankan program atau perintah yang diberikan [5].

Penelitian yang disusun oleh Elly Mufidah, Siti Nurajizah, dan Abdul Abas menjelaskan pembuatan alat pengendali atap jemuran otomatis dapat berjalan sesusuai dengan yang diharapkan dan perlu adanya pengembangan lebih lanjut agar dapat merespon kondisi-kondisi yang lain, misalnya: secara otomatis atap akan tertutup pada jam 6 sore dan terbuka pada jam 7 pagi, walaupun tidak ada cahaya atau air pada jam tersebut, serta alat dapat mengkomunikasikan keadaan terkini atap kepada pemilik rumah melalui SMS. Penggunaan sensor yang lebih sensitif juga menjadi pertimbangan terhadap keberhasilan alat [6]. Dalam perancangan dan pembuatan prototype yang dubuat menggunakan sensor cahaya (Light Dependent Resistor), Sensor Pendeteksi Air sebagai masukan mikrokontroler Arduino Uno, dan IC L298N sebagai penggerak motor yang terdapat pada penjemur pakaian. Hasil prototype penjemuir pakaian yang dihasilkan bekerja secara otomatis [7]. Hasil akhir sebuah sistem kontroler yang dapat menjemur dan mengeringkan pakaian secara otomatis, jika kondisi cuaca hujan maka jemuran akan 
ditarik kedalam ruangan pengering untuk melakukan pengeringan pakaian. Pakaian mulai kering setelah kondisi kelembaban ruangan pengering semakin berkurang [8].

Penelitian selanjutnya dilakukan oleh Alhen Dwi Darusman, Mohammad Dahlan dan F. Shoufika Hilyana menjelaskan Pengendali yang akan digunakan berbasis Arduino Uno dengan Mikrokontroller ATmega 328 dengan bahasa pemrogaman, yaitu bahasa C. Dari hasil perancangan diketahui bahwa rangkaian dapat bekerja dengan baik yaitu ketika cuaca cerah jemuran pakaian berapa diluar ruangan dan ketika cuaca mendung atau hujan jemuran pakaian bergerak masuk ke dalam ruangan tertutup. Hal ini terlihat dari sensor dapat bekerja dan outputnya seperti LED dan kipas angin berfungsi (aktif) [9].

Dalam perancanga dam pembuatan jemuran otomatis(smart clothesline), masalah-masalah yang harus diselasaikan adalah meliputi sistem pengendali jemuran, arsitektur perangkat keras, meliputi: perangkat elektronik dan mekanik dari keterangan diatas maka penulis padukan untuk merealisasi jemuran otomatis yang efektif dan efisien dengan mendesain ulang dari bentuk jemuran otomatis (smart clothesline) yang telah diteliti sebelumnya. Alat yang akan diimplementasikan ini lebih praktis, mudah digunakan. Alat ini mempunyai prinsip kerja jemuran akan menutup dan membuka penutup jemuran pada saat hujan tiba atau malam dan cuaca panas, sehingga membantu untuk mempermudah pemakaiannya.

\section{Metodologi Peneltian}

Dalam penelitian ini menggunakan metode rancang bangun, yang diawali dariperancangan dan pembuatan perangkat keras(hardware) elektronik dan mekanik jemuran otomatis(smart clothesline), selanjutnya dibuatlah perancangan dan pembuatan perangkat lunak (software) sistem kendali intensitas cahaya dan tetes air hujan dan tahap terakhir pembuatan atau implementasi prototype dan pengujianjemuran otomatis(smart clothesline).

\subsection{Waktu Dan Tempat Pelaksanaan}

Penelitian ini dilakukan mulai bulan Mei 2018 sampai selesai, dengan mengambil tempat di laboratorium teknik digital, Universitas Putera Batam.

\subsection{Analisis Awal Metode Pengumpulan Data}

Untuk mengumpulkan data penelitian, penulis menggunakan dua metode yaitu:

a. Studi Kepustakaan Penulis mencari dan mempelajari tentang minimum sistem board arduino uno, sensor cahaya (LDR) dan sensor air hujan baik itu dari textbooks, e-books dan jurnal-jurnal penelitian jemuran otomatis yang pernah di teliti.

b. Studi EksperimenPenulis melakukan eksperimen ataupun percobaan secara langsung dengan pengambilan data pada prototype alat penjemur pakaian otomatis berbasis arduino uno dengan menitik beratkan pada tingkat sensitifitas sensor cahaya (LDR), sensor air hujan dan kecepatan respon dari motor servo dalam melakukan gerakan atau perubahan gerakan sudut posisi motor servo.

\subsection{Perancangan Penelitian}

Adapun tahapan perancangan dan pembuatan jemuran otomatis (smart clothesline)dalam penelitian inidilakukanmenjadi beberapa tahap dan bagian yaitu sebagai berikut:

a. Perancangan Hardware baik elektronik maupun mekanik bertujuan untuk merancang peralatan/rangkaian pendukung unruk sistem yang akan dibuat. Pada perancangan hardware prototype alat penjemur pakain otomatis. Instrumen dan komponen Elektronika dan mekanik yang digunakan terdiri atas:

1. Arduino Uno

2. Sensor Cahaya

3. Sensor Hujan

4. Motor Servo $8 \mathrm{Vdc}$

5. Power Supply 12 Vdc

6. Kabel Penghubung

7. Besi galvalum dan alumunium ukuran $3 / 8$ inch

8. Kain parasut

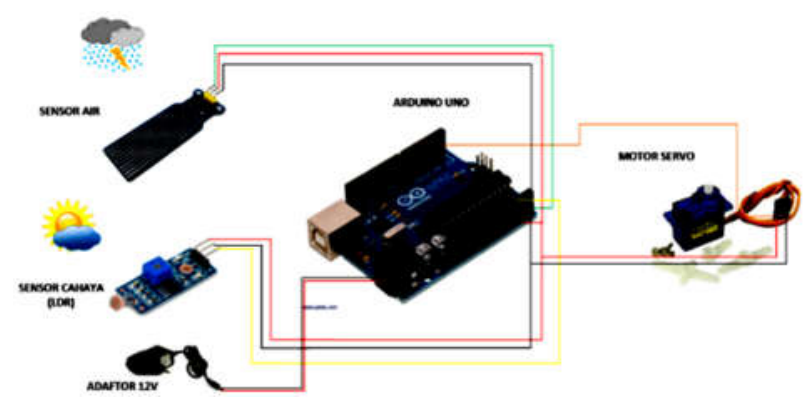

Gambar 1. Rangkaian Hardware Komponen Elektronik

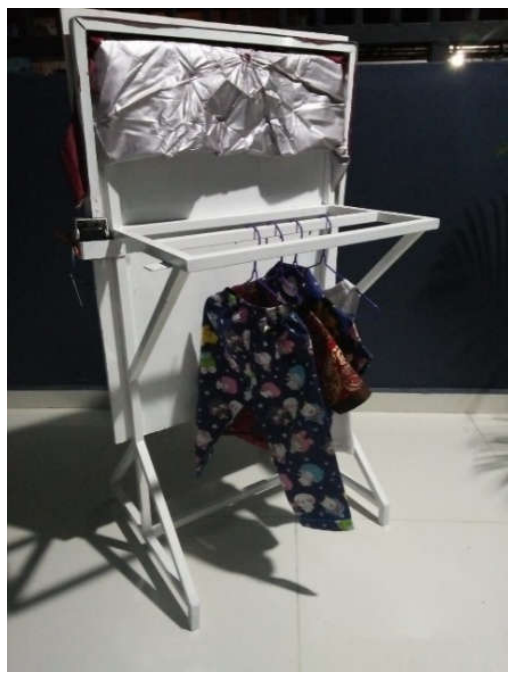

Gambar 2. Prototipe Smart Clothesline

b. Spesifikasi Rancangan Alat Spesifikasi alat yang akan dugunakan untuk membuat alat jemuran otomatis adalah sebagai berikut:

1. Menggunakan Arduino Uno sebagai pengendali.

2. Sensor cahaya (LDR) yang digunakan untuk mendeteksi cahaya perubahan siang dan malam.

3. Sensor hujan yang digunakan sebagai alat untuk pendeteksi turunnya hujan atau cuaca kondisi cerah.

4. Motorservo yang digunakan untuk menggerakan mengangkat penutup dan membuka jemuranotomatis (smart clothesline) dengan spesifikasi: Tegangan 
Maksimal 8,6 Volt DC, Output rpm 456, Torsi Maksimal $35 \mathrm{~kg} / \mathrm{cm}$.

5. Besi galvanis digunakan sebagai kerangka jemuran dengan ukuran prototype $50 \mathrm{~cm}$ x $30 \mathrm{~cm}$ x $100 \mathrm{~cm}$.

6. Alumunium digunakam sebagai kerangka penutup yang digerakkan oleh motor servo.

c. Perancangan software dilakukan untuk memudahkan di dalam pengoperasian alat nantinya, yang perlu diperhatikan pada perancangan software adalah langkah pembuatan rancangan program, yang bisa dilihat Gambar 3 di bawah ini:

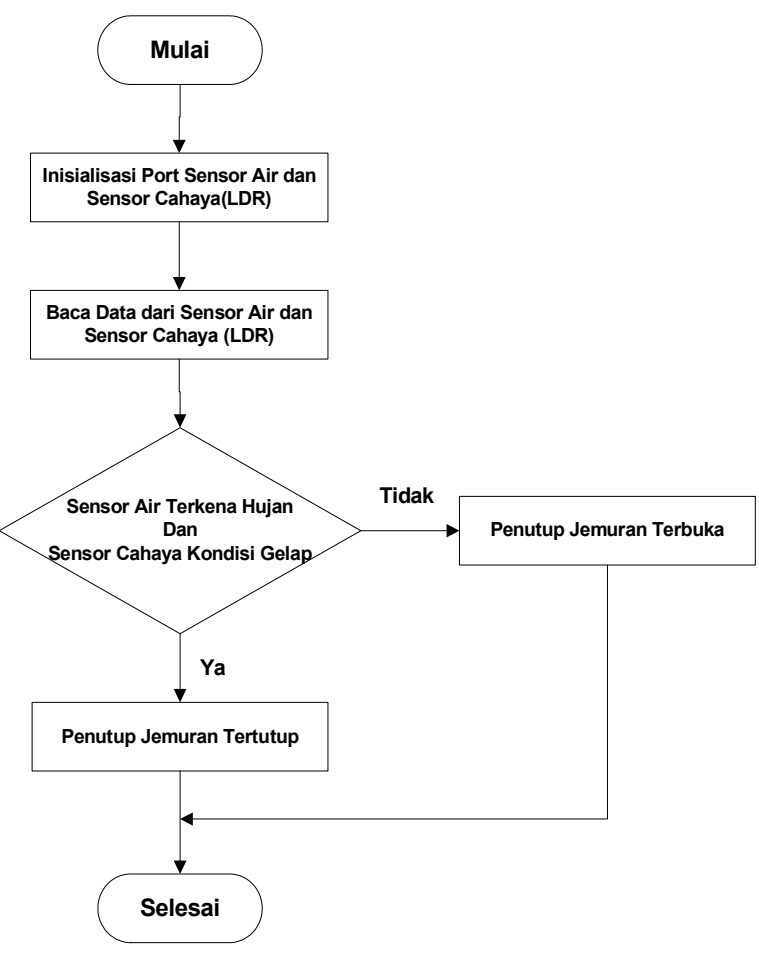

Gambar 3. Flowchart Alur Kerja Prototype Penjemuran Pakaian Otomatis

Pseudo Code Program software smart clothesline yang dirancang sebagai berikut.

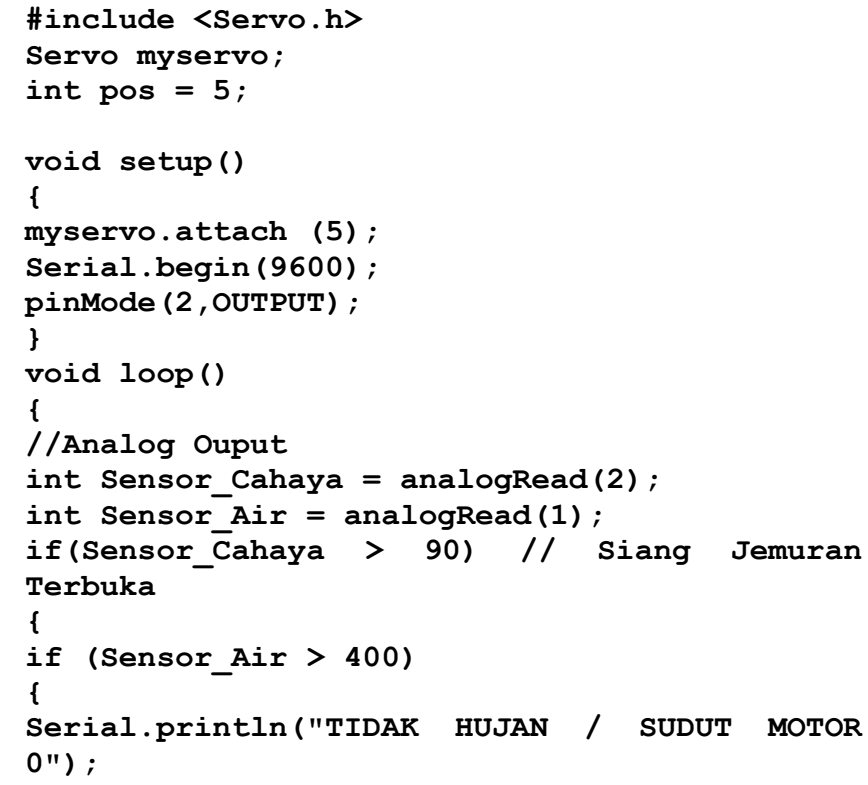

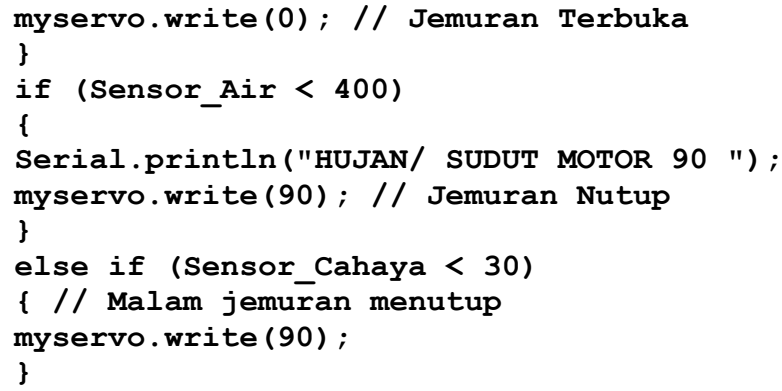

\section{HaSil dan PeMbahasan}

Pada bagian hasil dan pembahasan terdiri dari beberapa pengujian yaitu pengujian komponen-komponen elektronik penyusun sistem pada alat yang akandibuat, dengan tujuan untuk membuktikan bahwa komponenkomponen alat yang dibuat sudah sesuai dengan rancangan yang telah dibuat. Dan yang terakhir pengujian sistem secara keseluruhan dalam bentuk prototype.

Rangkaian catu daya adalah hal yang pertama yang harus diperhatikan mengingat catu daya adalah sumber tegangan dari alat. Apabila catu daya tidak bekerja dengan baik, maka akan mempengaruhi kinerja sistem dari alat tersebut sehingga alat tidak dapat bekerja maksimal. Rangkaian Power supply atau catu daya ini berfungsi untuk mensuplay tegangan ke seluruh rangkaian. Pengujian pada bagian rangkaian power supply ini dapat dilakukan dengan mengukur tegangan keluaran dari rangkaian power supply dengan menggunakan alat ukur voltmeter. Dari hasil pengukuran diperoleh tegangan keluaran dari power supply sebesar 12 volt dc.

Tabel 1. Hasil pengukuran tegangan output rangkaian power supply/ catu daya

\begin{tabular}{lcc}
\hline No & Sumber Tegangan & $\begin{array}{l}\text { Vout 5V De Dengan } \\
\text { Output IC regulator } \\
\text { LM7805 }\end{array}$ \\
\hline \hline $\mathbf{1}$ & $12 \mathrm{~V}$ & $5 \mathrm{~V}$ \\
\hline $\mathbf{2}$ & $12 \mathrm{~V}$ & $5 \mathrm{~V}$ \\
\hline $\mathbf{3}$ & $12 \mathrm{~V}$ & $5 \mathrm{~V}$ \\
\hline $\mathbf{4}$ & $12 \mathrm{~V}$ & $5 \mathrm{~V}$ \\
\hline
\end{tabular}

Berdasarkan hasil pengukuran catu daya pada IC LM 7805 diberi nilai input 12 volt menghasilkan output 5 volt. Dalam pengujian sensor hujan ini sangatlah mudah, yaitu dengan cara meneteskan air di atas papan panel sensortersebut, sehingga pada saat power supply di ONkan sensor ini dapat bekerja dengan baik. ditandai dengan bekerjanya sebuah relay yang mengubah kontak NO (normally open) pada relay tersebut menjadi NC (normally close), begitupun dengan kontak NC menjadi NO. Pada saat air pada papan panel sensor tersebut mengering maka relay akan berhenti bekerja dan mengubah kontak yang tadinya NC menjadi NO kembali.

Tabel 2. Hasil pengukuran tegangan pada rangkaian sensor Air

\begin{tabular}{ccc}
\hline No & $\begin{array}{c}\text { Perlakuan pada } \\
\text { Sensor }\end{array}$ & Tegangan Output (V) \\
\hline \hline $\mathbf{1}$ & Tidak ditetesi air & $4,7 \mathrm{~V}$ \\
\hline $\mathbf{2}$ & Ditetesi air & $1,3 \mathrm{~V}$ \\
\hline
\end{tabular}


Pengujian sensor cahaya ini dapat dilakukan dengan meletakkan sesor cahaya tersebut didalam ruangan minim cahaya. Pada saat pengujian sensor cahaya ini, LDR dapat bekerja dengan baik ditandai dengan bekerjanya sebuah relay yang mengubah kontak NO (normally open) menjadi NC (normally close). Dengan berubahnya intensitas cahaya yang jatuh pada LDR, maka nilai hambatannya pun akan ikut berubah. Seiring dengan perubahan nilai hambatan tersebut, maka akan mempengaruhi output dari rangkaian sensor tersebut.

Tabel 3. Hasil pengukuran tegangan pada rangkaian sensor LDR

\begin{tabular}{lcc} 
No & $\begin{array}{c}\text { Perlakuan pada } \\
\text { Sensor }\end{array}$ & Tegangan Ouput (V) \\
\hline \hline $\mathbf{1}$ & Terang & $4,8 \mathrm{~V}$ \\
\hline $\mathbf{2}$ & Gelap & $1,8 \mathrm{~V}$ \\
\hline
\end{tabular}

Pengujian Motor Servodilakukan dengan cara memberikan pulsa random sehingga didapat sudut putaran dari motor servo tersebut. Berikut tabel pengujian:

Tabel 4. Hasil pengujian motor servo

\begin{tabular}{ccc}
\hline No & Pulsa & $\begin{array}{c}\text { Sudut Putar Motor } \\
\text { Servo (Derajat) }\end{array}$ \\
\hline \hline $\mathbf{1}$ & 1100 & 0 \\
\hline $\mathbf{2}$ & 2000 & 45 \\
\hline $\mathbf{3}$ & 2800 & 90 \\
\hline
\end{tabular}

Berdasarkan hasil pengujian motor servoJenis (RDS $3135 \mathrm{MG}$ High Torque servo $35 \mathrm{Kg}$ ) saat motor servo diberikan pulsa sesusai dengan nilai diatas didapat sudut perputaran yang cukup untuk mengerakan kran. Ketika motor servo diberikan pulsa dibawah dan diatas nilai 1100 dan 2800 tidak ada perubahan putaran, sehingga bisa ditarik kesimpulan bahwa nilai 1100 dan 2800 adalah pulsa minimum dan maksimum untuk kedua motor servo tersebut.

Prototype penjemur pakaian otomatis berbasis Arduino Uno dibuat supaya ketika turun hujan pakaian yang sedang di jemur tidak mengalami kehujanan dan basah terkena air. Pemanfaatan teknologi pada jemuran pakaian menciptakan sebuah jemuran pintar yang inovatif dalam kebutuhan rumah tangga yang dapat membaca kondisi cuaca sehingga secara otomatis dapat keluar dan masuk ke dalam rumah atau garasi rumah secara otomatis. Untuk dapat membaca keadaan cuaca, prototype jemuran pintar yang dibuat ini membutuhkan sensor cahaya (LDR) yang berfungsi sebagai pembaca keadaan cahaya disaat gelap dan terang, dan juga sensor air sebagai pendeteksi cuaca hujan. Untuk melakukan uji coba alat penjemur pakaian otomatis dilakukan dengan berbagai kondisi yaitu dalam kondisi cerah dan dalam keadaan hujan.

Pengujian prototypesystem jemuran otomatis (smart clothesline) saat cuaca cerah. Pada penelitian ini cahaya senter diasumsikan sebagai cahaya matahari. Jadi seperti terlihat pada Gambar 4 ketika sensor LDR diberikan cahaya maka penutup jemuranakan terbuka oleh motor servo yang mendapatkan perintah dari arduino, karena input dari LDR dibaca oleh Arduino. Jemuran itu akan berhenti sendirinya ketika sudut gerak motor servo pembuka jemuranmembentuk sudut $0^{\circ}$.

Tabel 4. Hasil Pengujian Sensor LDR Saat diberikan Cahaya pada Prototype Smart Clothesline

\begin{tabular}{lccc}
\hline No & Input & \multicolumn{2}{c}{ Output } \\
\cline { 2 - 4 } & $\begin{array}{c}\text { Sensor Cahaya } \\
(\text { LDR) }\end{array}$ & $\begin{array}{c}\text { Waktu } \\
\text { (Menit) }\end{array}$ & $\begin{array}{c}\text { Penutup } \\
\text { Jemuran }\end{array}$ \\
\hline \hline $\mathbf{1}$ & Cahaya Terang & 1 & Terbuka \\
\hline $\mathbf{2}$ & Cahaya Terang & 2 & Terbuka \\
\hline $\mathbf{3}$ & CahayaTerang & 3 & Terbuka \\
\hline $\mathbf{4}$ & Cahaya Terang & 4 & Terbuka \\
\hline $\mathbf{5}$ & Cahaya Terang & 5 & Terbuka \\
\hline
\end{tabular}

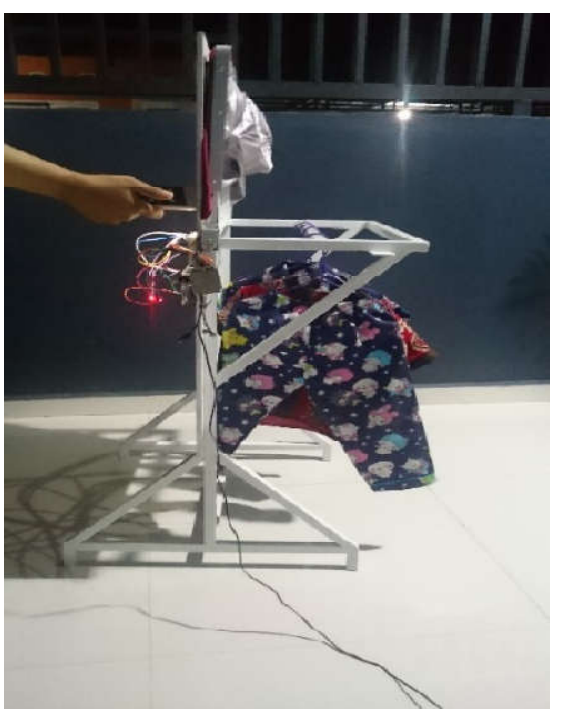

Gambar 4. Ketika LDR diberikan Cahaya

Pengujian prototypesystem jemuran otomatis (smart clothesline) saat malam hari. Pada penelitian ini cahaya senter diasumsikan sebagai cahaya matahari ditutup. Jadi seperti terlihat pada Gambar 5 ketika sensor LDR ditutup tidak diberikan cahaya maka penutup jemuranakan menetup oleh motor servo yang mendapatkan perintah dari arduino, karena input dari LDR dibaca oleh arduino. Jemuran itu akan berhenti sendirinya ketika sudut gerak motor servo penutup jemuran membentuk sudut $90^{\circ}$.

Tabel 5. Hasil Pengujian Sensor LDR pada Saat Tidak diberikan cahaya pada Prototype Smart Clothesline

\begin{tabular}{lccc}
\hline \multirow{2}{*}{ No } & \multicolumn{1}{c}{ Input } & Output \\
\cline { 2 - 4 } & Sensor Cahaya (LDR) & $\begin{array}{c}\text { Waktu } \\
\text { (Menit) }\end{array}$ & Penutup Jemuran \\
\hline \hline $\mathbf{1}$ & Tidak Ada Cahaya & 1 & Tertutup \\
\hline $\mathbf{2}$ & Tidak Ada Cahaya & 2 & Tertutup \\
\hline $\mathbf{3}$ & Tidak Ada Cahaya & 3 & Tertutup \\
\hline $\mathbf{4}$ & Tidak Ada Cahaya & 4 & Tertutup \\
\hline $\mathbf{5}$ & Tidak Ada Cahaya & 5 & Tertutup \\
\hline
\end{tabular}




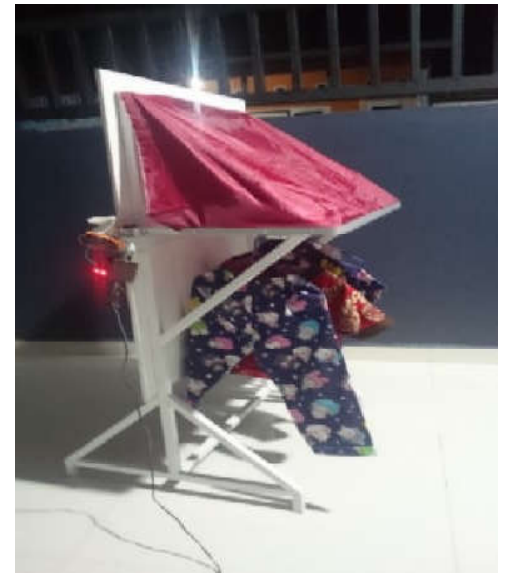

Gambar 5. LDR Tidak Lagi Diberi Cahaya

Pengujian prototypesystem jemuran otomatis (smart clothesline) saat hujan. Pada penelitian ini sensor air diberikan tetesan air yang diasumsikan sebagai tetesan air hujan. Jadi seperti terlihat pada Gambar 6 ketika sensor airdicelupkan pada wadah berisi air maka penutup jemuranakan menetup oleh motor servo yang mendapatkan perintah dari arduino, karena input dari sensor air dibaca oleh arduino. Jemuran itu akan berhenti sendirinya ketika sudut gerak motor servo penutup jemuran membentuk sudut $90^{\circ}$.

Tabel 6. Hasil Pengujian Sensor AirSaat diberikan Tetesan Air pada Prototype Smart Clothesline

\begin{tabular}{lccc}
\hline No & Input & Output \\
\cline { 2 - 4 } & Sensor Air & $\begin{array}{c}\text { Waktu } \\
\text { (Menit) }\end{array}$ & $\begin{array}{c}\text { Penutup } \\
\text { Jemuran }\end{array}$ \\
\hline \hline $\mathbf{1}$ & Tetesan Air Sedikit & 1 & Terbuka \\
\hline $\mathbf{2}$ & Tetesan Air Sedikit & 2 & Tertutup \\
\hline $\mathbf{3}$ & Tetesan Air Sedang & 1 & Tertutup \\
\hline $\mathbf{4}$ & Tetesan Air sedang & 2 & Tertutup \\
\hline $\mathbf{5}$ & Tetesan Air Banyak & 1 & Tertutup \\
\hline
\end{tabular}

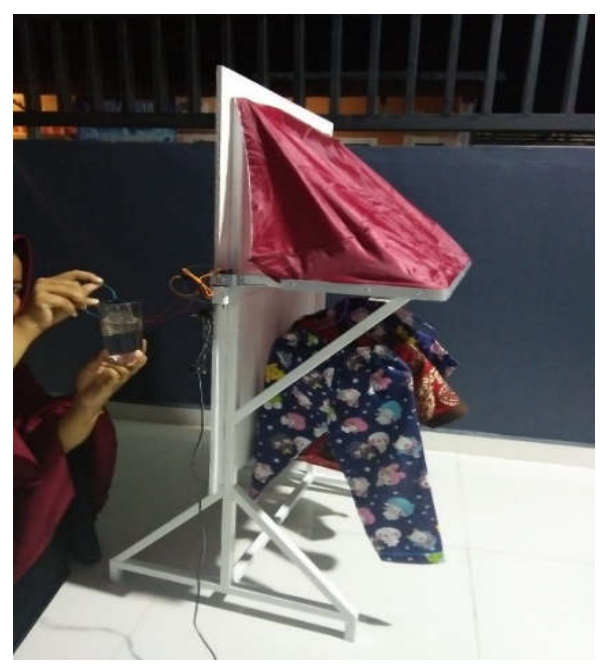

Gambar 6. Sensor Air Diberi Tetesan Air

Pengujian prototypesystem jemuran otomatis (smart clothesline) saat tidak hujan. Pada penelitian ini sensor air tidak diberi tetesan air padayang diasumsikan sebagai tetesan air hujan. Jadi seperti terlihat pada Gambar 7 ketika sensor air tidakdicelupkan pada wadah berisi air maka penutup jemuranakan terbuka oleh motor servo yang mendapatkan perintah dari arduino, karena input dari sensor air dibaca oleh arduino. Jemuran itu akan berhenti sendirinya ketika sudut gerak motor servo penutup jemuran membentuk sudut $0^{\circ}$

Tabel 6. Hasil Pengujian Sensor Air Saat tidak diberikan Tetesan Air pada Prototype Smart Clothesline

\begin{tabular}{lccc}
\hline \multirow{2}{*}{ No } & \multicolumn{1}{c}{ Input } & Output \\
\cline { 2 - 4 } & Sensor Air & $\begin{array}{c}\text { Waktu } \\
\text { (Menit) }\end{array}$ & Penutup Jemuran \\
\hline \hline $\mathbf{1}$ & Tetesan Air Sedikit Sedikit & 1 & Terbuka \\
\hline $\mathbf{2}$ & Tida Ada Tetesan Air & 2 & Terbuka \\
\hline $\mathbf{3}$ & Tidak adaTetesan Air & 1 & Terbuka \\
\hline $\mathbf{4}$ & Tidak adaTetesan Air & 2 & Terbuka \\
\hline $\mathbf{5}$ & Tidak adaTetesan Air & 1 & Terbuka \\
\hline
\end{tabular}

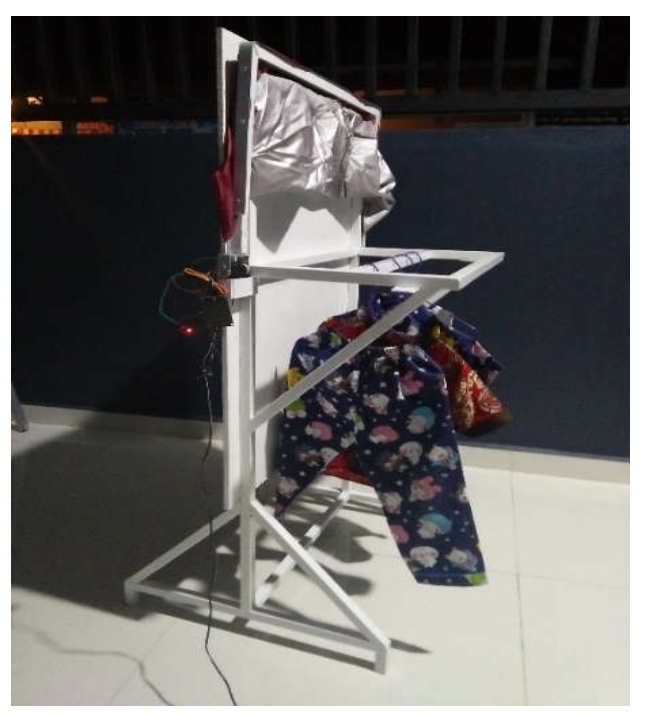

Gambar 7. Sensor Air Tidak Ditetesi Air

Adapun hasil pengamatan dari hasil pengujian jemuran otomatis (smart clothesline) keseluruhan ditunujkkan oleh Tabel. 7sebagai berikut:

Tabel 7. Hasil Pengujian Keseluruhan pada Prototype Smart Clothesline

\begin{tabular}{lccc}
\hline No & Input & \multicolumn{2}{c}{ Output } \\
\cline { 2 - 4 } & Sensor Cahaya & Sensor Air & Penutup \\
& (LDR) & & Jemuran \\
\hline \hline $\mathbf{1}$ & Terang & Cerah & Terbuka \\
\hline $\mathbf{2}$ & Malam & Cerah & Tertutup \\
\hline $\mathbf{3}$ & Terang & Hujan & Tertutup \\
\hline $\mathbf{4}$ & Malam & Hujan & Tertutup \\
\hline
\end{tabular}




\section{Kesimpulan}

Adapun kesimpulan yang didapatkan dari hasil pembahasan adalah sebagai berikut:

1. Berdasarkan hasil dari pengujian yang dilakukan, motor servo penggerak alat penutup dan pembuka penutup jemuran pakaian otomatis (smart clotheline) berbasis arduino uno telah bekerja sesuai dengan yang diharapkan yaitu ketika Sensor cahaya diberi cahaya dan sensor air tidak diberi tetesan air maka penutup jemuran terbuka, ketika Sensor cahaya tidak diberi cahaya dan sensor air tidak diberi tetesan air maka penutup jemuran menutup, ketika Sensor cahaya diberi cahaya dan sensor air diberi tetesan air maka penutup jemuran menutup, dan ketika Sensor cahaya tidak diberi cahaya dan sensor air diberi tetesan air maka penutup jemuran menutup.

2. Arduino Unomerupakan minimum system yang harga nya murah dan terjangkau sehinggadigunakan sebagai pengendali utama dalam alat ini dapat bekerja dengan baik dalam menjalankan setiap program atau perintah yang diberikan, dan kelebihan dari smart clothesline ini yaitu praktis, mudah dalam penggunaannya dan tidak terlalu membutuhkan tempat yang luas dalam penggunaannya

\section{Daftar Pustaka}

[1] Rismawan, E., Sulistyanti, S., dan Trisanto, A. 2012. "Rancang Bangun Prototype Penjemur Pakaian Otomatis Berbasis Mikrikontroller ATMega8535”. JITET - Jurnal Informatika dan Teknik Elektro Terapan. Vol. 1 (1): 4957.

[2] Kahimpong, R, L., Umboh,M., dan Maluegha, B. 2016. "OTOMATIS BERBASIS ARDUINO UNO ATMEGA32". Jurnal Online Poros Teknik Mesin. Vol. 6 (1): 69-81.

[3] Laksono, A, B., Abidin. Z. 2014. " Perancangan Dan Pembuatan Alat Jemuran Otomatis Sensor Deteksi Basah". Jurnal Teknik A. Vol 6 (2), ISSN No. 20850859, Hal 593-596

[4] Manurung, A. D. E., Harahap, U. 2017 " Simulasi Kendali Jemuran Otomatis Automatic clothesline control ". JESCE-Journal of Electrical and System Control Engineering.," vol. 1, (1),

[5] Siswanto, D., Winardi, S. 2015. “Jemuran Pakaian Otomatis Menggunakan Sensor Hujan dan Sensor LDR Berbasis Ardiuno Uno". e-Jurnal NARODROID. Vol. 1 (2015): 66-73.

[6] Mufida, E., Nurajizah, S., dan Abas, A. 2013. "Pengendali Atap Jemuran Otomatis dengan Sensor Cahaya Berbasis Mikrokontroller ATMega16". Konferensi Nasional Ilmu Sosial dan Teknologi: 269274.

[7] Hakim, A.R., Lailiyah, S., dan Suntoro, F., A. 2018. "Prototipe Penjemur Pakaian Otomatis Berbasis Arduino Uno". JUST TI. Vol. 10 (1): 16-21.

[8] Feriska, A., Triyanto, D. 2017. "Rancang Bangun Penjemur Dan Pengering Pakaian Otomatis Berbasis Mikrokontroler". Jurnal Coding Sistem Komputer Untan. Vol. 05 (2): 67-76.

[9] Darusman, A. D., Dahlan, M., Hilyana, F. S. 2018“RANCANG BANGUN PROTOTYPE ALAT PENJEMUR PAKAIAN OTOMATIS," SIMETRIS, vol. Vol. 9 No.1. 